\title{
The problems of violence against women in international law
}

\author{
V. V.Chernikov ${ }^{1}$, O. K. Goncharenko ${ }^{2}$ \\ ${ }^{1}$ Lobachevsky State University of Nizhny Novgorod, \\ 23, ul. Gagarina, Nizhny Novgorod, 603022, Russian Federation \\ 2 Moscow State Institute of International Relations (MGIMO University), \\ 76, pr. Vernadskogo, Moscow, 119454, Russian Federation
}

For citation: Chernikov, Valery V., Olga K. Goncharenko. 2021. “The problems of violence against women in international law”. Vestnik of Saint Petersburg University. Law 3: 803-819.

https://doi.org/10.21638/spbu14.2021.319

The problems of violence against women and domestic violence were reflected in Goal No. 5 of the 2030 Agenda for Sustainable Development, which calls for gender equality and empowerment of women and girls while addressing such challenges as elimination of all forms of discrimination against women and girls; eradication of violence against women and girls in the public and private sphere, including human trafficking, sexual and other forms of exploitation; liquidation of all harmful practices, in particular forced marriages and female genital mutilation. In this article, the authors examine existing conventional and doctrinal definitions and qualifications of the terms "violence against women" and "domestic violence" in international law, explore international legal aspects of prevention and combatting violence against women and domestic violence, conduct a comprehensive analysis of a conceptual framework related to these offences, and present basic approaches to the concept of domestic violence. The authors also examine the link between two core international universal and regional legal acts in this field - Convention on the Elimination of all Forms of Discrimination against Women and Council of Europe Convention on preventing and combatting violence against women and domestic violence. The authors derive a new understanding of the due diligence principle (a well-known principle/standard in international law) with regard to violence against women and domestic violence issues, clarify its key components while codifying states' main obligations in this sphere. In conclusion, the authors deduce that the questions of elimination of discrimination against women and eradication of violence against women can only be considered collectively, confirming the validity of the theory of a genderbased approach to the issue, which is adhered to by international human rights bodies.

Keywords: women's rights, domestic violence, prevention of violence, Istanbul Convention, gender equality, discrimination, elimination of discrimination, due diligence.

\section{Introduction}

The system of protecting women from violence and domestic violence is based on the universal principle of human rights and freedoms protection, which was for the first time enshrined in the Charter of the United Nations in $1945^{1}$. In order to specify the provisions of the Charter, the Universal Declaration of Human Rights and Covenants on civil and political, as well as economic, social and cultural rights were adopted in $1948^{2}$ and

${ }_{1}$ UN Charter. Accessed February 25, 2021. https://www.un.org/ru/charter-united-nations.

2 The Universal Declaration of Human Rights. 1948. Accessed June 1, 2021. https://www.un.org/en/ about-us/universal-declaration-of-human-rights.

(c) St. Petersburg State University, 2021 
$1966^{3}$, which resulted in building commitments to defend vulnerable groups of people, including women.

The common system of human rights protection is being developed both at universal and regional levels, within which special measures have been taken to raise the effectiveness of women's protection, including from violence and domestic violence, to identifying and eliminating the root causes of these phenomena.

The analysis of international practice has shown that the framework of women's protection, including from violence, is generally developed by states through the conclusion of international multilateral treaties, preceded by the adoption of declaratory documents in this field. The main role in this area belongs to the United Nations and the Council of Europe, on whose initiatives the core documents in the sphere of women's protection were developed. To date, however, the legally binding international instrument aimed at combatting violence against women and domestic violence in the form of the Istanbul Convention ${ }^{4}$ has been adopted only within the Council of Europe (Alisievich 2017; Zhelin'ska 2017; Sekowska-Kozlowska 2020).

In the article the authors conduct a comparative analysis of core universal international treaties and the Council of Europe Convention on Preventing and Combating Violence against Women and Domestic Violence (Šimonović 2014).

The purpose of this article is to undertake a comprehensive international legal review of existing approaches to qualify such acts as violence against women and domestic violence, to examine conceptual and legal aspects of understanding domestic violence (Walsh, Spangaro, Soldatic 2015; Dutton, Nicholls 2005; Stark 2006; Johnson 2006), to reveal the connection between elimination of gender discrimination and prevention of violence against women and domestic violence and to identify main obligations of the states to combat these phenomena based on the due diligence principle.

\section{Basic research}

\subsection{The definition and characterization of "violence against women" and "domestic violence" in international law}

The term "violence against women" is mentioned in titles of international treaties at universal and regional levels: Declaration on the Elimination of Violence Against Women, adopted by the United Nations General Assembly (henceforth referred to as UN GA) in 19935; 1994 Inter-American Convention on the Prevention, Punishment, and Eradication of Violence against Women ${ }^{6} ; 2011$ Council of Europe Convention on Preventing and Combating Violence against Women and Domestic Violence.

\footnotetext{
${ }^{3}$ International Covenant on Civil and Political Rights. 1966. Accessed June 1, 2021. https://www. ohchr.org/EN/ProfessionalInterest/Pages/CCPR.aspx.

4 Council of Europe Convention on Preventing and Combating Violence against Women and Domestic Violence. 2011. Accessed February 25, 2021. https://www.coe.int/en/web/conventions/full-list// conventions/rms/090000168008482e.

${ }^{5}$ Declaration on the Elimination of Violence Against Women. 1993. Accessed February 25, 2021. http://www.un.org/ru/documents/decl_conv/declarations/violence.shtml.

${ }^{6}$ Inter-American convention on the prevention, punishment and eradication of violence against women "Convention of Belem do Para". 1994. Accessed February 25, 2021. http://www.oas.org/juridico/ english/treaties/a-61.html.
} 
A woman that is exposed to domestic violence is defined as a "victim" in international law. International legal acts include the European Convention on the Compensation of Victims of Violent Crimes, opened for signature on November $24^{\text {th }}, 1983^{7}$ and the Declaration of Basic Principles of Justice for Victims of Crime and Abuse of Power adopted by the UN GA Resolution 40/34 of November $29^{\text {th }}, 1985^{8}$. Some other terms related to violence against women can be found in international documents: gender-based violence, attacks on women, rape, sexual assault, sexual exploitation or exploitation of prostitution, harassment, honor crimes, female genital mutilation, harmful practices against women and domestic violence. These terms are periodically reflected in the documents of the UN, the Council of Europe (henceforth referred to as $\mathrm{CoE}$ ) and the Organization for Security and Co-operation in Europe (henceforth referred to as OSCE).

In 1949 the UN GA approved the Convention for the Suppression of the Traffic in Persons and of the Exploitation of the Prostitution of Others9. The term "exploitation of prostitution" is reflected in the title. This term is most often used in the context of human trafficking prevention. In order to cover all situations related to violence against women, international legal acts include the term "domestic violence". Notably, there are variations used for the description of this phenomena, such as: domestic violence, family violence and intimate partner violence.

The UN GA adopted Resolutions titled "Domestic violence"10 in 1985 and 1990. These Resolutions recall the Economic and Social Council Resolution (henceforth referred to as ECOSOC) ${ }^{11}$ "On violence in the family" of May $24^{\text {th }}, 1984$.

Since the late 1980s, the term "violence against women" within the UN has been used by other main bodies of the Organization - the Commission on Human Rights (replaced with the Human Rights Council in 2006) - a subsidiary body of the UN GA, specialized institutions and human rights treaty bodies.

In 1989 and 1992 the Committee on the Elimination of Discrimination against Women ${ }^{12}$ adopted General recommendations No. $12^{13}$ and No. $19^{14}$ on violence against women ${ }^{15}$.

${ }^{7}$ European Convention on the Compensation of Victims of Violent Crimes. 1983. Accessed June 1, 2021. https://www.coe.int/en/web/conventions/full-list/-/conventions/rms/0900001680079751.

8 Declaration of Basic Principles of Justice for Victims of Crime and Abuse of Power. 1985. Accessed February 28, 2021. https://www.un.org/ru/documents/decl_conv/declarations/power.shtml.

9 Convention for the Suppression of the Traffic in Persons and of the Exploitation of the Prostitution of Others. Accessed February 25, 2021. https://undocs.org/ru/A/RES/317\%28IV\%29.

10 GA UN Resolution 40/36. 1985, 1990. Accessed February 25, 2021. https://undocs.org/ru/A/ RES/40/36; GA UN Resolution A/Res/45/114. Accessed February 25, 2021. https://undocs.org/ru/A/ $\mathrm{RES} / 45 / 114$.

${ }_{11}$ ECOSOC. 1984. Accessed June 1, 2021. https://www.unodc.org/documents/commissions/CCPCJ/ Crime_Resolutions/1980-1989/1985/A-RES-40-35.pdf

12 The UN treaty body, which monitors the implementation of the Convention on the Elimination of All Forms of Discrimination against Women by member States (henceforth referred to as CEDAW).

${ }^{13}$ CEDAW General Recommendation No. 12: violence against women. 1989. Accessed February 25, 2021. https://tbinternet.ohchr.org/Treaties/CEDAW/Shared\%20Documents/1_Global/INT_CEDAW_ GEC_5831_E.pdf.

${ }^{14}$ CEDAW General Recommendation No. 19: Violence against women. 1992. Accessed February 25, 2021. https://tbinternet.ohchr.org/Treaties/CEDAW/Shared\%20Documents/1_Global/INT_CEDAW_ GEC_3731_E.pdf.

${ }^{15}$ In 2017 another General Recommendation No. 35 with regard to violence against women was adopted. Accessed June 1, 2021. https://tbinternet.ohchr.org/_layouts/15/treatybodyexternal/Download. aspx? symbolno $=\mathrm{CEDAW} / \mathrm{C} / \mathrm{GC} / 35 \& \mathrm{Lang}=\mathrm{en}$. 
On March $4^{\text {th }}, 1994$, the UN Commission on Human Rights established the position of the Special Rapporteur on violence against women, its causes and consequences in accordance with its Resolution 1994/45 ${ }^{16}$.

In some cases, the term "violence against women" is defined further as corresponding to specific forms of violence like rape and sexual assault. Such an approach was implemented by the UN GA in the Resolution "Rape and abuse of women in the areas of armed conflict in the former Yugoslavia" of $1995^{17}$.

The UN Human Rights Council (henceforth referred to as UN HRC) has adopted several Resolutions on the intensification of efforts to prevent and eliminate all forms of violence against women and girls since $2009^{18}$, which address the following issues:

- ensuring due diligence in prevention of violence $(2010)^{19}$;

- ensuring due diligence in protection from violence $(2011)^{20}$;

- remedies for women who have been subjected to violence $(2012)^{21}$;

- preventing and responding to rape and other forms of sexual violence (2013) ${ }^{22}$;

- violence against women as a barrier to women's political and economic empowerment $(2014)^{23}$;

- preventing and responding to violence against women and girls, including indigenous women and girls $(2016)^{24}$;

- engaging men and boys in preventing and responding to violence against all women and girls $(2017)^{25}$.

In some UN HRC documents, girls are mentioned alongside women as a general term or in the context of a vulnerable social group.

The UN GA later again referred to the term "violence against women" when adopting relevant Resolutions including the Resolutions on the intensification of efforts to eliminate all forms of violence against women $\left(2009^{26}\right.$ and $\left.2013^{27}\right)$; on strengthening crime prevention and criminal justice responses to violence against women $(2010)^{28}$; on intensi-

16 Resolution 1994/45. Accessed June 1, 2021. https://www.ohchr.org/EN/Issues/Women/SRWomen/ Pages/SRWomenIndex.aspx.

17 The Resolution "Rape and abuse of women in the areas of armed conflict in the former Yugoslavia". 1995. Accessed June 1, 2021. https://undocs.org/en/A/RES/49/205.

18 Resolution A/HRC/RES/11/2. 2009. Accessed February 25, 2021. https://ap.ohchr.org/ Documents/R/HRC/resolutions/A_HRC_RES_11_2.pdf.

19 Resolution A/HRC/14/L.9/Rev.1. 2010. Accessed February 25, 2021. https://documents-dds-ny. un.org/doc/UNDOC/LTD/G10/144/13/PDF/G1014413.pdf?OpenElement.

20 Resolution A/HRC/17/L. 6. 2011. Accessed February 25, 2021. https://documents-dds-ny.un.org/ doc/UNDOC/LTD/G11/140/19/PDF/G1114019.pdf?OpenElement.

${ }^{21}$ Resolution A/HRC/20/L.10. 2012. Accessed February 25, 2021. https://www.ohchr.org/EN/ HRBodies/HRC/RegularSessions/Session20/Pages/ResDecStat.aspx.

22 Resolution A/HRC/23/L. 28. 2013. Accessed February 25, 2021. https://documents-dds-ny.un.org/ doc/UNDOC/LTD/G13/146/80/PDF/G1314680.pdf?OpenElement.

${ }^{23}$ Resolution A/HRC/26/L.26/Rev.1. 2014. Accessed February 25, 2021. https://documents-dds-ny. un.org/doc/UNDOC/LTD/G14/066/17/PDF/G1406617.pdf?OpenElement.

24 Resolution A/HRC/32/L. 28/Rev.1. 2016. Accessed February 25, 2021. https://documents-dds-ny. un.org/doc/UNDOC/LTD/G16/140/33/PDF/G1614033.pdf?OpenElement.

25 Resolution A/HRC/35/L. 15. 2017. Accessed February 25, 2021. https://documents-dds-ny.un.org/ doc/UNDOC/LTD/G17/165/70/PDF/G1716570.pdf?OpenElement.

26 Resolution A/RES/64/137. 2009. Accessed February 27, 2021. https://undocs.org/ru/A/RES/64/137.

27 Resolution A/RES/67/144. 2013. Accessed February 27, 2021. https://undocs.org/ru/A/RES/67/144.

${ }^{28}$ Resolution A/RES/65/228. 2010. Accessed February 27, 2021. https://undocs.org/ru/A/RES/65/228. 
fication of efforts to prevent and eliminate all forms of violence against women and girls: sexual harassment $(2019)^{29}$.

ECOSOC is a body that directly deals with these issues within the UN in the context of human rights protection by addressing the issue of "violence against women" and adopting relevant Resolutions, including the 2010 Resolution on strengthening crime prevention and criminal justice responses to violence against women ${ }^{30}$.

The term "violence against women" is also widely used in numerous international reports and studies such as the "Global and regional estimates of violence against women: prevalence and health effects of intimate partner violence and non-partner sexual violence" 31 prepared by the World Health Organization (henceforth referred to as WHO) in 2013.

Some other widely referred expressions include the so-called "honor crimes", "female genital mutilation" and "harmful practices against women". A group of independent UN experts have prepared the Report "Good practices in legislation on harmful practices against women" 32 .

Terms that entail children as boys and girls under the age of 18 such as "violence against women and girls", "sexual abuse of children", "sexual harassment of children" and "sexual exploitation of children" are not uncommon in international law practice. The UN HRC Resolution "Accelerating efforts to eliminate violence against women and girls: preventing and responding to violence against women and girls in digital contexts" 33 serves as an example of this.

The term "harassment" in employment is also well-known in international law. The International Labor Organization (henceforth referred to as ILO) adopted the Violence and Harassment Convention in $2019^{34}$, as well as the ILO Recommendation No. $206^{35}$.

The Council of Europe's statutory bodies have used terms related to domestic violence for some time. The Committee of Ministers of the Council of Europe (henceforth referred to as CM CoE) issued Recommendations "On violence in the family" 36 and "On social measures concerning violence within the family" 37 in 1985 and 1990 respectively. The Parliamentary Assembly of the Council of Europe (henceforth referred to as PACE)

\footnotetext{
${ }^{29}$ Resolution A/RES/73/148. 2019. Accessed February 27, 2021. https://undocs.org/ru/A/RES/73/148.

30 Resolution 2010/15. Accessed February 27, 2021. https://www.un.org/ecosoc/sites/www.un.org. ecosoc/files/documents/2010/res-2010-15.pdf.

31 Global and regional estimates of violence against women: prevalence and health effects of intimate partner violence and non-partner sexual violence. 2013. Accessed February 27, 2021. https://apps.who.int/ iris/bitstream/handle/10665/85241/WHO_RHR_HRP_13.06_eng.pdf?sequence=1.

32 Good practices in legislation on harmful practices against women. 2009. Accessed February 27, 2021. https://www.un.org/womenwatch/daw/egm/vaw_legislation_2009/Final\%20report\%20EGMGPLVAW.pdf.

33 Resolution A/HRC/38/L.6. 2018. Accessed February 27, 2021. https://documents-dds-ny.un.org/ doc/UNDOC/LTD/G18/195/62/PDF/G1819562.pdf?OpenElement.

${ }^{34}$ C190 - Violence and Harassment Convention, 2019 (No. 190). Accessed February 27, 2021. https://www.ilo.org/dyn/normlex/en/f?p=NORMLEXPUB:12100:0::NO:12100:P12100_INSTRUMENT_ ID:3999810:NO.

35 R206 - Violence and Harassment Recommendation, 2019 (No. 206). Accessed February 27, 2021. https://www.ilo.org/dyn/normlex/en/f?p=NORMLEXPUB:12100:0::NO::P12100_ILO_CODE:R206.

36 Recommendation R(85)4. 1985. Accessed February 27, 2021. https://search.coe.int/cm/Pages/ result_details.aspx?ObjectId=09000016804f120d.

${ }_{37}$ Recommendation No. R (90) 2. 1990. Accessed February 27, 2021. https://search.coe.int/cm/Pages/ result_details.aspx?ObjectId=09000016804e91bc.
} 
adopted the Resolutions "Domestic violence against women"38, "Children who witness domestic violence" 39 , "Protection orders for victims of domestic violence" 40 ; the Council of Europe Congress of Local and Regional Authorities (henceforth referred to as CLRAE) has adopted the Resolution "Combating domestic violence against women"41.

The approach to using the term "rape" can be observed in the PACE Resolution "Rape of women, including marital rape" 42 .

The term "violence against women" is reflected in later CM CoE Recommendations "On the protection of women against violence" ${ }^{3}$; the PACE Resolutions "Combating violence against women: towards a Council of Europe convention"44, "Violence against women in Europe" ${ }^{45}$, "Promoting best practices in tackling violence against women" "Systematic collection of data on violence against women" 47.

Terminology related to the so-called "honor crimes" is widely used within the Council of Europe. In particular, the PACE Committee on Equal Opportunities for Women and Men issued the Report "So-called "honour crimes"' 48 ; PACE adopted the Resolution "Female genital mutilation in Europe"49; CM CoE adopted the Declaration "On the need to intensify the efforts to prevent and combat female genital mutilation and forced marriage in Europe" 50 .

The term "sexual exploitation" is reflected in the 2015 CLRAE Resolution "The fight against trafficking in human beings and their sexual exploitation: the role of cities and regions" ${ }^{\prime \prime}$. In 2017, the Council of Europe adopted the Convention on the Protection of

38 Recommendation 1582 (2002). Accessed February 27, 2021. http://assembly.coe.int/nw/xml/XRef/ Xref-XML2HTML-en.asp?fileid=17055\&lang=en.

39 Recommendation 1905 (2010) Final version. Accessed February 27, 2021. http://assembly.coe.int/ nw/xml/XRef/Xref-XML2HTML-en.asp?fileid=17825\&lang=en.

40 Resolution 1853 (2011) Final version. Accessed February 27, 2021. http://assembly.coe.int/nw/xml/ XRef/Xref-XML2HTML-en.asp?fileid=18053\&lang=en.

${ }^{41}$ Resolution 279(2009). Accessed February 27, 2021. https://search.coe.int/congress/Pages/result details.aspx?ObjectId=0900001680719ebf.

${ }^{42}$ Resolution 1691 (2009). Accessed February 27, 2021. http://assembly.coe.int/nw/xml/XRef/XrefXML2HTML-en.asp?fileid=17784\&lang=en.

${ }^{43}$ Recommendation Rec(2002) 5 of the Committee of Ministers to member states on the protection of women against violence. Accessed February 27, 2021. https://rm.coe.int/09000016805e2612.

44 Resolution 1635 (2008). Accessed February 27, 2021. http://assembly.coe.int/nw/xml/XRef/XrefXML2HTML-en.asp?fileid=17682\&lang=e.

45 Resolution 1963 (2013) Final version. Accessed February 27, 2021. http://assembly.coe.int/nw/xml/ XRef/Xref-XML2HTML-en.asp?fileid=20301\&lang=en.

46 Resolution 2084 (2015). Accessed February 27, 2021. http://assembly.coe.int/nw/xml/XRef/XrefXML2HTML-en.asp?fileid=22288\&lang=en.

${ }^{47}$ Resolution 2101 (2016). Accessed February 27, 2021. http://assembly.coe.int/nw/xml/XRef/XrefXML2HTML-en.asp?fileid=22555\&lang=en.

48 Document 9720 as of 7 March 2003. Дата обращения 27 февраля, 2021. http://assembly.coe.int/ nw/xml/XRef/X2H-Xref-ViewHTML.asp?FileID=10068\&lang=EN.

49 Resolution 2135 (2016). Accessed February 27, 2021. http://assembly.coe.int/nw/xml/XRef/XrefXML2HTML-en.asp?fileid=23176\&lang=en.

${ }^{50} \operatorname{Decl}(13 / 09 / 2017)$ (Adopted by the Committee of Ministers on 13 September 2017 at the 1293rd meeting of the Ministers' Deputies). Accessed February 27, 2021. https://search.coe.int/cm/Pages/result_ details.aspx?ObjectId=0900001680747e57.

${ }_{51}$ Resolution 196 (2005). Accessed February 27, 2021. https://search.coe.int/congress/Pages/result_ details.aspx?ObjectId=0900001680718cff. 
Children against Sexual Exploitation and Sexual Abuse ${ }^{52}$, also known as "the Lanzarote Convention".

It should be emphasized that the term "violence against women" must be differentiated from the gender-based violence (i. e., violence on the grounds of sex) issues related to it, to which PACE devoted the Resolutions "Action to combat gender-based human rights violations, including the abduction of women and girls"53; "Women in the armed forces: promoting equality, putting an end to gender-based violence" 54; "Protecting refugee women and girls from gender-based violence" 55 .

The terms "attacks against women" and "harassment" are present in the PACE Resolutions "Recent attacks against women: the need for honest reporting and a comprehensive response"56; "Promoting parliaments free of sexism and sexual harassment"57.

In OSCE's practice, its main bodies also use terminology related to violence against women. Indeed, the OSCE Committee of Ministers gave forth the Decisions 15/05 (2005 $)^{58}$, $7 / 14(2015)^{59}, 4 / 18(2018)^{60}$ on "Preventing and combating violence against women", and the OSCE Parliamentary Assembly adopted the Resolution "On violence against women" $(2009)^{61}$.

In 2017, the OSCE Committee of Ministers issued the Decision on "Strengthening efforts to combat all forms of child trafficking, including for sexual exploitation, as well as other forms of sexual exploitation of children" 62 .

After a coherent and methodical specification of terms, the authors consider it necessary to proceed to their definitions present in the beforementioned international legal acts and documents.

The term "gender-based violence" is defined in CEDAW General recommendation No. 19 as "a form of discrimination that seriously inhibits women's ability to enjoy rights and freedoms on a basis of equality with men" ${ }^{63}$. In that General recommendation,

52 Convention on Protection of Children against Sexual Exploitation and Sexual Abuse. Accessed February 27, 2021. https://rm.coe.int/CoERMPublicCommonSearchServices/DisplayDCTMContent?doc umentId=090000168046e1da.

${ }^{53}$ Recommendation 1868 (2009). Accessed February 27, 2021. http://assembly.coe.int/nw/xml/XRef/ Xref-XML2HTML-en.asp?fileid=17730\&lang=en.

${ }_{54}$ Resolution 2120 (2016). Accessed February 27, 2021. http://assembly.coe.int/nw/xml/XRef/XrefXML2HTML-en.asp?fileid=22939\&lang=en.

55 Resolution 2159 (2017). Accessed February 27, 2021. http://assembly.coe.int/nw/xml/XRef/XrefXML2HTML-en.asp?fileid=23700\&lang=en.

56 Resolution 2093 (2016). Accessed February 27, 2021. http://assembly.coe.int/nw/xml/XRef/XrefXML2HTML-en.asp?fileid=22494\&lang=en.

57 Resolution 2274 (2019). Accessed February 27, 2021. http://assembly.coe.int/nw/xml/XRef/XrefXML2HTML-en.asp?fileid=27614\&lang=en.

58 MC. DEC/15/05 as of 6 December, 2005. Accessed February 27, 2021. https://www.osce.org/files/f/ documents/c/8/17451.pdf.

59 MC. DEC/7/14/Corr.1 as of 5 December, 2015. Accessed February 27, 2021. https://www.osce.org/ files/f/documents/8/e/130721.pdf.

${ }^{60}$ MC. DEC/4/18 as of 7 December, 2018. Accessed February 27, 2021. https://www.osce.org/files/f/ documents/e/e/406019.pdf.

${ }^{61}$ HDIM. OSCE. PA/0267/09 as of 1 October, 2009. Accessed February 27, 2021. https://www.osce. org/files/f/documents/3/2/39065.pdf.

${ }^{62}$ MC. DEC/7/17 as of 8 December, 2017. Accessed February 27, 2021. https://www.osce.org/files/f/ documents/f/b/362016.pdf.

${ }^{63}$ CEDAW General recommendation No. 19: Violence against women. 1992. Accessed February 27, 2021. https://tbinternet.ohchr.org/Treaties/CEDAW/Shared\%20Documents/1_Global/INT_CEDAW_ GEC_3731_E.pdf. 
CEDAW elaborates that the notion "discrimination against women", defined in Article 1 of the Convention on the Elimination of all Forms of Discrimination Against Women, also includes the term "gender-based violence": "violence that is directed against a woman because she is a woman or that affects women disproportionately" 64 . CEDAW later substantiated "gender-based violence" to point out the gender-based causes and consequences of such violence, as "gender-based violence against women" in General recommendation No. 35 that was meant to be an update to General recommendation No. 19. CEDAW adheres to the opinion that "gender-based violence against women is one of the fundamental social, political and economic means by which the subordinate position of women with respect to men and their stereotyped roles are perpetuated" 65 , and that "violence is a critical obstacle to the achievement of substantive equality between women and men and to the enjoyment by women of their human rights and fundamental freedoms, as enshrined in the Convention on the Elimination of all Forms of Discrimination Against Women" 66.

The term "victim" is defined in Article 1 of the Declaration of Basic Principles of Justice for Victims of Crime and Abuse of Power. By that definition, "victims" means "persons who, individually or collectively, have suffered harm, including physical or mental injury, emotional suffering, economic loss or substantial impairment of their fundamental rights, through acts or omissions that are in violation of criminal laws operative within Member States, including those laws proscribing criminal abuse of power". Meanwhile, Article 2 states that "a person may be considered a victim regardless of whether the perpetrator is identified, apprehended, prosecuted or convicted and regardless of the familial relationship between the perpetrator and the victim". The term "victim" also includes, where appropriate, "the immediate family or dependants of the direct victim and persons who have suffered harm in intervening to assist victims in distress or to prevent victimization". The designation of a "victim" "shall be applicable to all, without distinction of any kind, such as race, colour, sex, age, language, religion, nationality, political or other opinion, cultural beliefs or practices, property, birth or family status, ethnic or social origin, and disability".

The term "violence against women" is defined in Articles 1 and 2 of the Declaration on the Elimination of Violence against Women of 1993. It means "any act of gender-based violence that results in, or is likely to result in, physical, sexual or psychological harm or suffering to women, including threats of such acts, coercion or arbitrary deprivation of liberty, whether occurring in public or in private life". This term is understood to encompass the following (but is not limited to): "a) Physical, sexual and psychological violence occurring in the family, including battering, sexual abuse of female children in the household, dowry-related violence, marital rape, female genital mutilation and other traditional practices harmful to women, non-spousal violence and violence related to exploitation; b) Physical, sexual and psychological violence occurring within the general community, including rape, sexual abuse, sexual harassment and intimidation at work, in educational institutions and elsewhere, trafficking in women and forced prostitution; c) Physical, sexual and psychological violence perpetrated or condoned by the State, wherever it occurs".

${ }^{64}$ Ibid.

65 CEDAW General recommendation No. 35: gender-based violence against women, updating general recommendation No. 19. 2017. Accessed February 27, 2021. https://tbinternet.ohchr.org/_layouts/15/ treatybodyexternal/Download.aspx?symbolno=CEDAW/C/GC/35\&Lang=en.

66 Ibid. 
Under Article 3 of the Council of Europe Convention on preventing and combating violence against women and domestic violence of 2011, "violence against women" is defined "as a violation of human rights and a form of discrimination against women" and shall mean "all acts of gender-based violence that result in, or are likely to result in, physical, sexual, psychological or economic harm or suffering to women, including threats of such acts, coercion or arbitrary deprivation of liberty, whether occurring in public or in private life". Violence against women constitutes a violation of human rights and genderbased discrimination, however the drafters of the Convention have pushed the boundaries of this phenomenon further by making provisions for the term "economic harm" to be correlated to psychological harm, thereby expressing a new approach to the interpretation of human rights. Thus, we see that the definition of "violence against women" given in the Istanbul Convention is broader than the one given in the Declaration on the Elimination of Violence against Women; it also covers economic harm and suffering. At the same time, practically no legislation of European states contains such definitions, which is the reason why they are beginning to form in the law enforcement practice.

The Istanbul Convention, alongside the definition of "violence against women", contains the definition of "domestic violence" which is understood as "all acts of physical, sexual, psychological or economic violence that occur within the family or domestic unit or between former or current spouses or partners, whether or not the perpetrator shares or has shared the same residence with the victim". An all-encompassing definition of domestic violence is for the first time introduced by the Istanbul Convention.

The Convention contains yet another definition - "gender-based violence against women", that is "violence that is directed against a woman because she is a woman or that affects women disproportionately". At the same time, the Convention clarifies that the term "women" also includes girls under the age of 18 .

According to the Convention, a "victim" shall mean "any natural person who is subject to the conduct specified in points a and b", which are points that provide definitions for the terms "violence against women" and "domestic violence".

It is important to note that in the adoption of the document on May $11^{\text {th }}, 2011$, the Explanatory Report to the Council of Europe Convention on preventing and combating violence against women and domestic violence (henceforth referred to as the Explanatory Report, Explanatory Report to the Istanbul Convention) was submitted for a complete presentation of prerequisites and factors which had been facilitative for its adoption. Par. 41 and 42 of the Explanatory Report explain that "domestic violence" includes "intimatepartner violence between current or former spouses or partners and inter-generational violence which typically occurs between parents and children"67.

Scholars clearly delineate the terms "domestic violence" and "violence in the family", characterizing "domestic violence" on the basis of the location of the scene of violence, while classifying "violence in the family" on the basis of characteristics of the relationship between the victim and the abuser (Winstok 2007).

As can be seen by the definitions, "violence against women" and "domestic violence" constitute four forms: physical, sexual, psychological and economic violence.

67 Explanatory Report to the Council of Europe Convention on preventing and combating violence against women and domestic violence. 2011. Accessed February 28, 2021. https://rm.coe.int/CoERMPublicCommonSearchServices/DisplayDCTMContent?documentId=09000016800d383a. 
Under Article 35 of the Explanatory Report to the Istanbul Convention, physical violence refers to "bodily harm suffered as a result of the application of immediate and unlawful physical force", while also encompassing violence that may result in the death of the victim ${ }^{68}$. Examples of such violence include beating, spanking, pushing, arson attack, use of a weapon or a knife (Garcia-Moreno et al. 2005). Physical violence is often accompanied by acts of abuse and aggressive behavior in order to gain complete control over a woman (Browne, Salomon, Bassuk 1999).

Under Article 36 of the Istanbul Convention, sexual violence, including rape, is understood as: "a) engaging in non-consensual vaginal, anal or oral penetration of a sexual nature of the body of another person with any bodily part or object; b) engaging in other non-consensual acts of a sexual nature with a person; $c$ ) causing another person to engage in non-consensual acts of a sexual nature with a third person".

Under par. 189 of the Explanatory Report to the Istanbul Convention it is clarified that physical violence covers "all forms of sexual acts which are performed on another person without his or her freely given consent and which are carried out intentionally", meanwhile "the interpretation of the word 'intentionally' is left to domestic law, but the requirement for intentional conduct relates to all the elements of the offence".

The WHO defines sexual violence as "forcing the partner to have sexual intercourse without his consent or forcing him into relations he finds humiliating or degrading; mutilation during intercourse; forcing unprotected sex" ${ }^{19}$. This definition is duplicated by a number of specialists who consider sexual violence as "sex without mutual consent, against desire, with the use of physical force, threats, intimidation, forcible sexual intercourse after beatings, sex as a means of humiliation and insult" (Garcia-Moreno et al. 2015).

The Istanbul Convention (Article 33) defines psychological violence as "intentional conduct of seriously impairing a person's psychological integrity through coercion or threats". Concurrently, under par. 181 of the Explanatory Report to the Istanbul Convention it is explained that psychological violence "refers to a course of conduct rather than a single event. It is intended to capture the criminal nature of an abusive pattern of behaviour occurring over time - within or outside the family". At the same time, the Explanatory Report states that "psychological violence often precedes or accompanies physical and sexual violence in intimate relationships (domestic violence)" and that "it may also occur in any other type of setting, for example in the work place or school environment".

The WHO lists insults, blackmail, restriction of access to information, education, medical services as examples of psychological violence ${ }^{70}$.

Economic violence, not yet contained in positive international law with a definition, remains the most under researched. On the doctrinal level it is understood as "the act of controlling and monitoring the behavior of an individual in terms of the use and distribution of money, as well as the constant threat of deprivation of economic resources" (Miskulin 2020,115). This form of violence is considered to be very dangerous as it creates

68 Ibid.

69 Global and regional estimates of violence against women: prevalence and health effects of intimate partner violence and non-partner sexual violence. 2013. Accessed March 1, 2021. https://apps.who.int/iris/ bitstream/handle/10665/85239/9789241564625_eng.pdf.

70 The world health report 2002: reducing risks, promoting healthy life. Accessed March 1, 2021. https://www.who.int/whr/2002/en/whr02_en.pdf?ua=1. 
prerequisites to perpetration of psychological, physical and sexual violence with impunity due to the fact that the victim becomes dependent on the abuser. Economic dependence makes a woman especially vulnerable and increases the probability of domestic violence (Pisklakova-Parker, Sinelnikov 2008).

Currently, three main approaches to understanding domestic violence have been developed in the doctrine of international law. Despite the prevalence of a gender approach, however, understanding domestic violence as a family conflict and hybrid model represented by the theory of Michael Johnson remain relevant.

Perceiving domestic violence as a family conflict focuses on the manifestation of single, equivalent acts of aggression between partners, in which men and women are equally exposed to violence that is structural in nature and has a specific cause (Walsh, Spangaro, Soldatic 2015). Proponents of this approach argue that individuals, being guided by patterns of behavior that they witnessed in childhood or themselves being victims of physical violence, use it to resolve conflicts within the family or between intimate partners (Straus 1977). It is based on the lack of balance between partners which results in growing tensions within the family and consequently increases the risk of violence occurring (Sagrestano, Heavey, Christensen 1999). This assumption is confirmed by numerous studies in which the act of violence against an intimate partner is directly related to the presence of permanent stressful situations within the family (Mihalic, Elliott 1997).

Family conflict researchers believe that the occurring violence is symmetrical, that is, men and women are equal victims of such violence (Dutton, Nicholls 2005). As a refutation of this approach, one can refer to research of scientists who make distinctions of the forms and extent of violence inflicted by men against women and vice versa (Allen, Swan, Raghavan 2009; Gerstenberger, Williams 2013). According to them, violence of women against men manifests itself as a response to their actions in a less violent form and does not generate fear and control over men, thereby not introducing any restrictions into men's lives.

The gender-based approach (feministic domestic violence model) is fundamentally different from the approach of viewing domestic violence as a family conflict. Its proponents believe that men are much more likely than women to commit acts of violence in intimate relationships and everyday life (Levinson 1989; Dobash, Dobash 1979; Nazroo 1995).

Michael Johnson's theory seeks to address existing differences in doctrine and practice, confirming the validity of both approaches (Meier 2015). Johnson's differentiation theory quickly gained popularity among feminist and anti-feminist scholars and practitioners (Stark 2009, Frederick 2008). The point of the theory is to distinguish different groups of the population, among which the questions of violence against women and domestic violence are being examined. The typology of Johnson defines four forms of violence: situational couple violence, being committed equally by men and women; intimate terrorism, common for men; violent resistance, common for women; mutual violent control (Johnson 2008).

At the same time, it should be noted that despite existing discussions international human rights bodies take the position that violence against women is cross-sectoral and it is the main obstacle to their empowerment. Therefore, the questions of eliminating discrimination against women and combatting violence against women are considered by them cumulatively, thus affirming the theory of a gender approach to the problem. 
In the international law doctrine, the term "intimate partner violence", being derived from the term "domestic violence", is defined in different ways by researches depending on the division of a particular concept of the term "domestic violence". As a result, the proponents of the family conflict approach describe intimate partner violence as "illegal strategies used by individuals to resolve interpersonal conflicts in general and between intimate partners in particular", and the violence itself is defined by them as "an act committed with intent or a possible intent to use harm, physical pain or injury to another person" (Straus, Gelles, Steinmetz 1980).

The definition of intimate partner violence provided by the proponents of the family conflict approach has been criticized by researchers of the feministic domestic violence model due to the symmetrical approach to gender-based perception by the former and due to a limited scope in regard to the forms of violence (Johnson 1995). They have proposed a new definition of intimate partner violence against women: "abuse of power by a spouse, an intimate partner (be it a man or a woman) or a former spouse or partner which results in humiliation, loss of control and security and an onset of a feeling of powerlessness experienced by a woman who is a direct victim of ongoing or repeated physical, psychological, economic, sexual, verbal and/or spiritual abuse. Abuse of women also includes constant threats or forcing women to witness violence against their children, other relatives, friends and pets" (DeKeseredy 1997).

Summarizing the above, it is possible to conclude that all beforementioned forms of violence depending on when they are committed may be attributed to the designations of "violence against women" and "domestic violence".

\subsection{The synergy of universal and regional international instruments on combating violence against women and domestic violence}

Beginning from 1980 and up to the present day, the UN and the Council of Europe have made efforts to eliminate the phenomena of violence against women, which is inextricably linked with the achievement of gender equality and eradication of discrimination against women.

The UN GA played an important role in reaching these goals when adopting the act on women's rights protection, which characterized all forms of discrimination against women as illegal - the Convention on the Elimination of All Forms of Discrimination against Women, which entered into force on $3^{\text {rd }}$ September $1981^{71}$.

A special body called the Committee on the Elimination of Discrimination against Women was established to monitor compliance with the obligations undertaken by the State parties to the Convention. The Committee is also vested with the right to make recommendations on any issue that appears to require additional attention. During its $54^{\text {th }}$ session, the UN GA adopted Resolution A/RES/54/4 as of 15 October $1999^{72}$, under which the Optional Protocol to the CEDAW was opened for signature and ratification by the States parties. Thus, the Committee obtained a mandate to consider complaints from the victims of violence, being a person, a group of persons or an organization who suffered from a violation of rights enshrined in CEDAW.

${ }^{71}$ Convention on the Eliminations of All Forms of Discrimination against Women. 1981. Accessed June 1, 2021. https://www.un.org/womenwatch/daw/cedaw/text/0360795R.pdf.

72 Resolution A/RES/54/4. 1999. Accessed June 1, 2021. https://undocs.org/ru/A/RES/54/4. 
In 1989, 1992 and 2017 the Committee adopted General Recommendations No. 12, 19 and 35 on gender violence against women. Despite the fact that the Committee initially examined the question of violence against women in its General Recommendation No. 12, it was General Recommendation No. 19, which contained a comprehensive and detailed thematic overview providing a basis for the future work on the subject, that contributed to the acknowledgement of gender-based violence against women as a form of discrimination against them.

The Convention on the Elimination of all Forms of Discrimination Against Women has offered two fundamental innovations in regard to the development of the principle of non-discrimination for the international community:

- the Convention acts as an asymmetrical instrument to protect women from all forms of direct and indirect discrimination in various areas of social life;

- the Convention imposes obligations on the State parties to implement all necessary measures to improve the status of women as well as to empower them and expand their rights.

Therefore, the main goal of the Convention is not only to hold the State parties responsible for implementation of the principle of equality between women and men but, at the same time, to ensure its implementation. On the 16th anniversary of the Universal Declaration of Human Rights, CEDAW stated that "the principle of equality between women and men and the ability of women to enjoy all fundamental rights and freedoms is not only an obligation of the State under the Convention, but also constitutes a principle of customary international law"73.

Some scholars believe that CEDAW General recommendation No. 19 finally makes an association between discrimination and violence. Some note that recognition of violence as a form of discrimination against women allowed to fill the gap in International human rights law which is represented by a lack of a binding ban on acts of violence, while at the same time doubting the sufficiency of such measures (Edwards 2012).

However, after some time it became obvious that there was a need to elaborate on the universal document dealing only with the questions of violence against women and domestic violence. In this regard, in 1993 the UN GA adopted a special act called Declaration on the Elimination of Violence against Women, which became the first international instrument addressing aspects of violence against women. For the first time, this document contains a definition of this phenomenon. Article 2 of the Declaration provides a list of cases that cover violence against women, but they are not limited to them, including the types of violence that occurs in the family (physical, sexual and psychological violence, including beatings, sexual coercion against girls, rape of the wife by the husband, damage to the female genitals, etc.). Thus, the concept of domestic violence is reflected in the Declaration only in the context of violence against women.

It is worth noting, that this Declaration and CEDAW General recommendation No. 19 accepted the idea that the States should follow the obligation of due diligence, in particular, to take positive measures to prevent violence against women and to protect them, to persecute persons responsible for violent acts and to compensate the victim of violence.

${ }^{73}$ Statement of the CEDAW Committee: The Universal Declaration of Human Rights at 60 and the CEDAW Committee (adopted 4 Nov. 2008, $42^{\text {nd }}$ sess.). Accessed March 1, 2021. http:// www.ohchr.org/ Documents/HRBodies/CEDAW/Statements/UDHR60. 
Nonetheless, the Declaration is of a recommendatory nature and has not been developed into the universal convention, the provisions of which would be binding on its States parties after the ratification.

At the regional level, the international community has achieved more success in eliminating violence against women and domestic violence. The Council of Europe can rightly be called the most progressive international organization that adopted the first binding legal instrument in this sphere - the Istanbul Convention, which characterizes some forms of violence as criminal offences that should be implemented into the national legislation of the States parties. On the basis of the Convention, a special monitoring mechanism has been established.

It is important to note that the Convention on the Elimination of all Forms of Discrimination Against Women is an anti-discrimination instrument that encompasses all forms of violence as a type of discrimination against women, while the Istanbul Convention directly defines violence against women as a form of discrimination and human rights violation, thus contributing to the elimination of other types of discrimination against women. Both Conventions treat violence against women as a form of discrimination, however one of them does it directly, while the other one follows an indirect approach.

The Istanbul Convention's advantage is that it codifies and further develops the standards of the Convention on the Elimination of all Forms of Discrimination Against Women by affirming the notions of violence against women and gender-based violence. It, for the first time, introduces an international definition of "domestic violence" and the principle of due diligence. Its elaborated standards already have a universal significance as they can be used by all States in the process of refining their national legislation.

The relationship between the Convention on the Elimination of all Forms of Discrimination Against Women and the Istanbul Convention established through the recognition of violence against women as a form of discrimination is reinforced by the concurrent activity of the monitoring mechanisms of the two conventions. Moreover, it can be concluded that CEDAW contributes to the strengthening of the Istanbul Convention's standards by encouraging European States to accede to it and ratify it in their concluding observations to the respective periodic reports of States parties.

\subsection{Due diligence as a basic approach to eliminate violence against women and domestic violence}

Due diligence is the founding and guiding principle embodied in the Declaration on the Elimination of Violence against Women. Later, it was further confirmed and elaborated upon in the Reports of the UN General Secretary and UN Special rapporteurs on violence against women, its causes and consequences, and the CEDAW General recommendation No. 19 on preventing and combating violence against women. Within the Council of Europe, this disposition is proclaimed as a principle of the Istanbul Convention, enacting processes known as the " $4 \mathrm{P}$ ": prevention, protection, persecution and partnership.

Systematization of the " $4 \mathrm{P}$ " elements is required in order to identify the core obligations of the States parties to the Istanbul Convention. Furthermore, the authors believe it is necessary for this principle to be entrenched at the national level of the Council of Europe member-states regardless of their participation in the Istanbul Convention in order 
to provide the national violence against women and domestic violence combating mechanisms with a direct and dynamic disposition.

The authors propose the following definition of " $4 \mathrm{P}$ ".

In order to prevent violence against women and domestic violence, states should:

- ensure effective work of law enforcement agencies;

- provide training for law enforcement officials and the judiciary, representatives of medical and social institutions so that they can effectively protect the rights of women;

- carry out preventive work with both the victims of violence and the offenders to prevent re-victimization;

- carry out large-scale public campaigns aimed at legal education of the society in the scope of women's rights protection in order to raise awareness on the impermissibility of using violence against women.

In order to provide protection and aid to victims of violence, states should:

- take measures to prevent re-victimization;

- ensure availability of general specialized support services, including crisis centers, hotlines, legal aid offices etc.;

- criminalize all forms of violence.

In order to implement the prosecution of offenders committing violent acts, states should:

- promptly implement necessary measures to investigate all cases of violence against women and domestic violence;

- provide victims of violence with immediate aid while at the same time evaluating possible risks for the victim;

- implement the institute of restraining and protection orders;

- treat domestic violence cases in the manner of public prosecution so that ex officio prosecution is carried out in an orderly manner in case the victim withdraws the charge $^{74}$.

In order to establish an integrated, complex and coordinated national policy of engagement between government bodies and non-governmental organizations, states should:

- seek to encourage states to recognize the issue of violence against women and domestic violence;

- take into account women's issues when developing national strategies and action plans;

- implement the principle of inter-agency cooperation between government bodies, the private sector, non-governmental organizations and mass-media at every level;

- allocate the necessary financial and human resources;

- support the work of non-governmental organizations;

${ }^{74}$ Factors highlighted by the European Court of Human Rights in the case of "Opuz v. Turkey" could in such an event be used as a guideline (Case of Opuz v. Turkey (Application no. 33401/02). Accessed March 1, 2021. http://hudoc.echr.coe.int/eng?i=001-92945). 
- ensure effective monitoring and statistical data collection for cases of violence against women and domestic violence.

\section{Conclusions}

In order to prevent and combat violence against women and domestic violence it is necessary to take a holistic approach to the problem, which entails solving it by eliminating the discrimination of women and inequality of women and men, as well as eradicating prevailing gender stereotypes in the society. Having analyzed existing approaches to understanding these phenomena, as well as based on the provisions of international legal acts in this sphere, the authors conclude that the gender theory is the most valid and applicable and it states that violence against women and domestic violence cannot be considered as a family conflict or conflict between two partners.

Nowadays we see that international organizations have recognized the problem of violence against women and domestic violence, and they have taken measures to overcome it. However, it is obvious that these measures represented by the international legal acts of a binding and recommendatory character should be implemented at the national level.

Following the analysis of regulatory and doctrinal provisions, the authors have provided new generalized knowledge for understanding the due diligence principle, which is well-known in international law. It prescribes an integrated approach to preventing and combating violence against women and domestic violence, approved by the Istanbul Convention as the "4Ps".

The authors have also revealed key components of this integrated approach, which is to eliminate discrimination against women, to eradicate inequality between men and women, as well as to root out prevailing gender stereotypes through a well-established system of national mechanisms in full compliance with universal and regional anti-discrimination requirements.

\section{References}

Alisievich, Ekaterina S. 2017. "Russia's accession to the Council of Europe Convention on preventing and combating violence against women and domestic violence 2011: Myth or reality?" Aktual'nye problemy sovremennogo mezhdunarodnogo prava: Materialy XV Mezhdunarodnogo kongressa "Blishchenkovskie chteniia", Part 3, 232-244. Moscow, RUDN Publ. (In Russian)

Allen, Christopher T., Suzanne C. Swan, Chitra Raghavan. 2009. “Gender symmetry, sexism, and intimate partner violence". Journal of Interpersonal Violence 24: 1816-1834.

Browne, Angela, Adrian Salomon, Shari S. Bassuk. 1999. "The impact of recent partner violence on poor women's capacity to maintain work". Violence Against Women 5/4: 393-426.

DeKeseredy, Walter S. 1997. Woman abuse: A sociological story. Toronto, Harcourt Brace.

Dobash, Emerson, Russel Dobash. 1979. Violence against wives. New York, The Free Press.

Dutton, Donald G., Nicholls, Tonia L. 2005. "The gender paradigm in domestic violence research and theory: Part 1 - the conflict of theory and data". Aggress. Violent Behavior 10: 680-714. https://doi. org/10.1016/j.avb.2005.02.001.

Edwards, Alice. 2012. Violence against women under International human rights law. Cambridge, Cambridge University Press. https://doi.org/10.1017/CBO9780511779671.

Frederick, Loretta. 2008. "Questions about family court domestic violence screening and assessment". Family Court Review 46 (3): 523-530.

Garcia-Moreno, Claudia, Cathy Zimmerman, Alison Morris-Gehring, Lori Heise, Avni Amin, Naeemah Abrahamas, Oswaldo Montoya, Padma Bhate-Deosthali, Nduku Kilonzo, Charlotte Watts. 2015. 
"Addressing violence against women: A call to action". The Lancet 385 (9978): 1685-1695. https://doi. org/10.1016/S0140-6736(14)61830-4.

Garcia-Moreno, Claudia, Lori Heise, Henrica Jansen, Mary Ellsberg, Charlotte Watts. 2005. "Violence against women”. Science 310 (5752): 1282-1283.

Gerstenberger, Caryn B., Kirk R. Williams. 2013. "Gender and intimate partner violence does dual arrest reveal gender symmetry or asymmetry?” Journal of Interpersonal Violence 28 (8): 1561-1578.

Johnson, Michael P. 1995. "Patriarchal terrorism and common couple violence: Two forms of violence against women". Journal of Marriage and the Family 57: 283-294.

Johnson, Michael P. 2006. "Conflict and Control: Gender Symmetry and Asymmetry in Domestic Violence". Violence Against Women 12 (11): 1003-1018.

Johnson, Michael P. 2008. A typology of domestic violence: Intimate terrorism, violent resistance, and situational couple violence. Illinois, Northeastern University Press.

Levinson, David. 1989. Family violence in cross-cultural perspectives. Newbury Park, CA, Sage.

Meier, Joan S. 2015. "Johnson's differentiation theory: Is it really empirically supported?" Journal of Child Custody 12: 4-24.

Mihalic, Sharon W., Elliott Delbert. 1997. "A social learning theory model of marital violence". Journal of Family Violence 12 (1): 21-47.

Miskulin, Ivan. 2020. "Economic violence against women in Croatia". Collegium Antropologicum 44 (3): 115-119. https://doi.org/10.5671/ca.44.3.1.

Nazroo, James. 1995. "Uncovering gender differences in the use of marital violence: The effect of methodology". Sociology 29: 475-494.

Pisklakova-Parker, Marina P., Andrew Sinelnikov. 2008. "Between silence and shout". Nasilie i sotsial'nye izmeneniia. Teoriia, praktika, issledovaniia 1: 4-46. (In Russian)

Sagrestano, Lynda M., Christopher L. Heavey, Andrew Christensen. 1999. "Perceived power and physical violence in marital conflict". Journal of Social Issues 55 (1): 65-79.

Sekowska-Kozlowska, Katarzyna. 2020. "The Istanbul Convention in Poland. Between the 'The war on gender' and legal reform”. International Law and Violence Against Women, eds Johanna Niemi, Lourdes Peroni, Vladislava Stoyanova, 259-275. London, Routledge.

Šimonović, Dubravka. 2014. "Global and regional standards on violence against women: The evolution and synergy of the CEDAW and Istanbul Conventions”. Human Rights Quarterly 36: 590-606.

Stark, Evan. 2006. "Commentary on Johnson's 'Conflict and control: Gender symmetry and asymmetry in domesticviolence”. Violence Against Women 12:1019-1025.https://doi.org/10.1177/1077801206293329.

Stark, Evan. 2009. "Rethinking custody evaluation in cases involving domestic violence". Journal of Child Custody 6 (3): 287-321.

Straus, Murray A. 1977. "Wife beating: How common and why?" Victimology 2: 443-458.

Straus, Murray A., Richard J. Gelles, Suzanne K. Steinmetz. 1980. Behind closed doors: Violence in the American family. New Brunswick, N. J., Transaction Publ.

Walsh, Jeannette, Joanne Spangaro, Karen Soldatic. 2015. "Global understandings of domestic violence". Nursing \& Health Sciences, John Wiley \& Sons 17 (1): 1-4.

Winstok, Zeev. 2007. "Toward an interactional perspective on intimate partner violence". Aggression and Violent Behavior 12 (3): 348-363.

Zhelin'ska, Eleonora. 2017. "Council of Europe Convention on preventing and combating violence against women and domestic violence, its general assessment and impact of Poland's accession (continuation)". Mezhdunarodnoe pravo i mezhdunarodnye organizatsii 2: 43-63. (In Russian)

Received: March 8, 2021

Accepted: June 9, 2021

Authors' information:

Valery V. Chernikov — Dr. Sci. in Law, Professor; chvv13@yandex.ru

Olga K. Goncharenko - PhD Student; goncharenko_ok@bk.ru 